\title{
Urgensi Nasab dalam Islam dan Silsilah Nasab Habaib di Indonesia
}

\author{
Abu Yazid Adnan Quthny \\ Universitas Islam Zainul Hasan Genggong Probolinggo \\ a.yazid.aq@gmail.com \\ Ahmad Muzakki \\ Universitas Islam Zainul Hasan Genggong Probolinggo \\ muzakkipasca@gmail.com
}

\begin{abstract}
Among the wisdoms of implementing marriage is to determine the status of offspring. According to Islam, a child born through a legal marriage has a clear lineage status. In this paper the author describes the existence of the habaib in Indonesia, the position of the lineage in Islam, the determination of the lineage at the time of the Prophet and modern times as well as the Arab views of the lineage. After going through the discussion, it can be concluded that the Arabs are a nation that pays great attention to and maintains their lineage and kinship, because they do not forget their ancestors. Meanwhile, in Islamic law, the lineage has a very important role. With the clarity of one's lineage status, the laws related to this will also be clear. For example, about marriage, inheritance and mahram relationships.
\end{abstract}

Keywords: Nasab, Habaib, Islam

\begin{abstract}
Abstrak
Diantara hikmah disyariatkannya pernikahan adalah untuk menentukan status keturunan. Menurut Islam anak yang lahir dengan jalan pernikahan yang sah memiliki status nasab yang jelas. Dalam tulisan ini penulis memaparkan tentang keberadaan habaib di Indonesia, kedudukan nasab dalam Islam, penentuan nasab pada zaman Nabi dan zaman modern serta pandangan orang arab terhadap nasab. Setelah melalui pembahasan didapartkan kesimpulan bahwa Bangsa Arab merupakan bangsa yang sangat memperhatikan dan menjaga nasab dan hubungan kekerabatan, karena mereka tidak lupa nenek moyang mereka. Sedangkan dalam hukum Islam, nasab mempunyai peran yang sangat penting. Dengan jelasnya status nasab seseorang, hukum-hukum yang berkait dengan hal ini juga akan jelas. Semisal tentang perkawinan, warisan dan hubungan mahram.
\end{abstract}

Kata Kunci : Nasab, Habaib, Islam 


\section{A. PENDAHULUAN}

Perkawinan yang sah dalam Islam merupakan pintu awal terbentuknya hubungan nasab. Keberadaan nasab sangatlah penting. Nasab menjadi penentu bagian warisan, perwalian, pengasuhan dan hal-hal lain yang berhubungan. Tanpa adanya hubungan nasab, maka banyak hal yang akan sulit untuk diselesaikan, khususnya dalam kasus-kasus yang berkaitan dengan fiqh munakahat.

Dalam tradisi arab, khususnya kalangan habaib, nasab memikili posisi yang sangat dominan. Bahkan dalam penentuan calon pasangan, nasab menjadi yang paling utama. Pernikahan bisa saja dibatalkan apabila diketahui calon suami bukan dari kalangan habaib atau syarif.

Di indonesia, kalangan ini ada dibeberapa daerah. Sebagian besar masih mempertahankan tradisinya, khususnya dalam pernikahan dan urgensi nasab. Penulis merasa perlu untuk memaparkan keberadaan habaib di Indonesia, kedudukan nasab dalam Islam dan pandangan orang arab terhadap nasab.

\section{B. PEMBAHASAN}

\section{Kedudukan Nasab Dalam Islam}

\section{a. Pengertian Nasab}

Keberadaan anak dalam keluarga merupakan sesuatu yang sangat berarti. Anak memiliki arti yang berbeda-beda bagi setiap orang. Anak merupakan penyambung keturunan, sebagai investasi masa depan, dan anak merupakan harapan untuk menjadi sandaran di kala usia lanjut. Ia dianggap sebagai modal untuk meningkatkan peringkat hidup sehingga dapat mengontrol status social orang tua.

Anak merupakan pemegang keistimewaan orang tua, waktu orang tua masih hidup, anak sebagai penenang dan sewaktu orang tua telah meninggal, anak adalah lambing penerus dan lambang keabadian. Anak mewarisi tanda-tanda kesamaan dengan orang tuanya termasuk ciri khas baik maupun buruk, tinggi, maupun rendah. Anak adalah belahan jiwa dan potongan daging orang tuanya. ${ }^{1}$

Begitu pentingnya eksistensi anak dalam kehidupan manusia, maka Allah SWT mensyari'atkan adanya perkawinan. Pensyari'atan perkawinan memiliki

\footnotetext{
${ }^{1}$ Yusuf al-Qadhawi, 2006, Halal dan Haram dalam Islam, Jakarta: Rabbani Press, hal. 15.
} 
tujuan antara lain untuk berketurunan (memiliki anak) yang baik, memelihara nasab, menghindarkan diri dari penyakit dan menciptakan keluarga yang sakinah. Sebagaimana firman Allah SWT yang berbunyi:

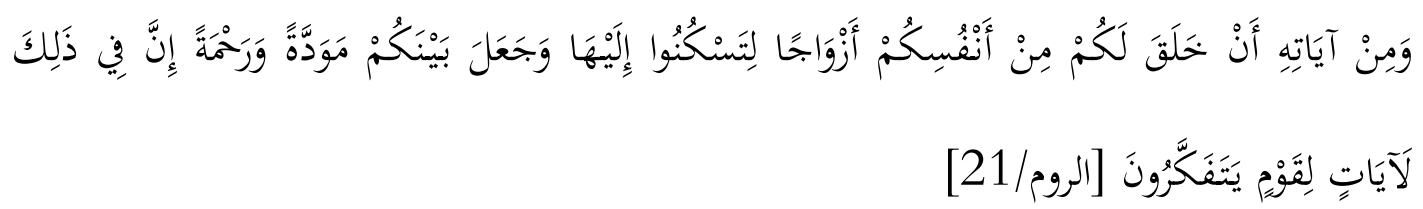

"Dan diantara tanda-tanda kekuasaannya adalah Dia menciptakan untukmu isteriisteri dari jenismu sendri supaya kamu cendrung dan merasa tentram kepdanya, dan dijadikannya diantara kamu rasa kasih dan sayang. Sesungguhnya pada yang demikian itu terdapat tanda-tanda bagi kaum yang berfikir." (Q.S. al-Rum: 21) ${ }^{2}$

Kata nasab yang terambil dari kata nasaba (Bahasa Arab) diartikan hubungan pertalian keluarga.4 Sedangkan dalam kamus bahasa Indonesia, kata nasab yang diadopsi dari bahasa arab tidak mengalami pergeseran arti yang signifikan. Nasab diartikan dengan Keturunan (terutama pihak Bapak) atau Pertalian keluarga. Sedangkan menurut Wahbah Az-Zuhaili nasab didefinisikan sebagai suatu sandaran yang kokoh untuk meletakkan suatu hubungan kekeluargaan berdasarkan kesatuan darah atau pertimbangan bahwa yang satu adalah bagian dari yang lain. Misalnya seorang anak adalah bagian dari ayahnya, dan seorang ayah adalah bagian dari kakeknya. Dengan demikian orang-orang yang serumpun nasab adalah orang-orang yang satu pertalian darah.

Dari pengertian bahasa tersebut, dapat dipahami bahwa nasab itu berarti hubungan darah yang terjadi antara satu orang dengan yang lain baik jauh maupun dekat. Namun, jika membaca literatur hukum Islam, maka kata nasab itu akan menunjuk pada hubungan keluarga yang sangat dekat, yaitu hubungan anak dengan orang tua terutama orang tua laki-laki.

Dalam ensiklopedi Islam disebutkan bahwa nasab adalah pertalian kekeluargaan berdasarkan hubungan darah melalui akad perkawinan yang sah. Nasab adalah hubungan antara orang yang satu dengan orang tua atau leluhurnya ke atas. Nasab atau keturunan yang artinya pertalian atau perhubungan merupakan indikasi yang dapat menentukan asal-usul seorang manusia dalam pertalian

${ }^{2}$ Departemen Agama RI, 2010, Al-Qur'an dan Terjemahnya, Bandung : Jabal Raudlotul Jannnah, hal. 387 
darahnya. Disyariatkannya pernikahan adalah untuk menentukan keturunan menurut Islam agar anak yang lahir dengan jalan pernikahan yang sah memiliki status yang jelas. Artinya anak itu sah mempunyai bapak dan mempunyai ibu. Akan tetapi, kalau anak itu lahir di luar pernikahan yang sah, maka anak itu statusnya menjadi tidak jelas hanya mempunyai ibu, tetapi tidak mempunyai bapak secara hukum.

\section{b. Klasifikasi Nasab}

Dalam ilmu nasab ada klasifikasi/pengelompokan status nasab seseorang:

1) Shohihun Nasab, adalah status nasab seseorang yang setelah melalui penelitian dan pengecekan serta penyelidikan ternyata sesuai dengan buku rujukan (buku H. Ali bin Ja'far Assegaf dan buku induk), yang bersangkutan dinyatakan berhak untuk mendapatkan buku dan dimasukkan namanya di dalam buku induk.

2) Masyhurun Nasab, adalah status nasab seseorang yang diakui akan kebenarannya namun tidak terdapat pada buku rujukan yang ada. Yang bersangkutan tidak bisa dimasukkan dalam buku induk. Kebenaran nasabnya didapat dari keterangan kalangan keluarganya sendiri dan ditunjang oleh beberapa literatur/buku yang dapat dipercaya, juga diakui oleh ahli-ahli silsilah terdahulu ditambah beberapa orang yang memang diakui kepribadiannya di masanya.

3) Majhulun Nasab, adalah status nasab seseorang setelah diadakan masa penyelidikan/pengecekan dan penelitian ternyata tidak didapatkan jalur nasabnya. Ada beberapa kemungkinan penyebab terjadinya status ini diantaranya: karena ketidak tahuan, kebodohan, keminiman pengetahuan masalah nasabnya ataupun niat-niat untuk memalsukan nasab.

4) Maskukun Nasab, adalah status nasab seseorang yang diragukan kebenarannya karena didalam susunannya terjadi kesalahan/terlompat beberapa nama. Hal ini dikarenakan terjadinya kelengahan sehingga tidak tercatatnya beberapa nama pada generasi tertentu.

5) Mardudun Nasab, adalah status nasab seseorang yang dengan sengaja melakukan pemalsuan nasab, yakni mencantum beberapa nama yang tidak memiliki hubungan dengan susun galur nasab yang ada. Ataupun menisbahkan 
namanya dengan qabilah tertentu bersandarkan dengan cerita/riwayah dari seseorang yang tidak memiliki ilmu nasab/individu yang mencari keuntungan ekonomi secara pribadi.

Ada beberapa kemungkinan yang menyebabkan yang bersangkutan bertindak memalsukan nasab ini sebagai contoh adalah karena yang bersangkutan hendak melamar Syarifah ataupun masalah warisan.

6) Tahtal Bahas (dalam pembahasan), adalah status nasab seseorang yang mana di dalamnya terjadi kesimpang siuran dalam susunan namanya. Hal ini banyak penyebabnya, diantaranya karena yang bersangkutan di tinggal oleh orang tuanya dalam keadaan masih kecil atau terjadinya kehilangan komunikasi dengan keluarganya atau terjadi kesalahan dalam menuliskan urutan-urutan namanya. Posisinya nasab ini bisa menjadi shohihun.nasab atau majhulun nasab atau mardudun nasab sesuai dengan hasil penyelidikan dan pengecekan yang dilakukan.

7) Math'unun Nasab, adalah status seseorang yang tertolak nasabnya karena yang bersangkutan terlahir dari hasil perkawinan di luar Syariat Islam. Tertolaknya nasab ini setelah melalui penelitian dan pengecekan juga dengan ditegaskan oleh beberapa orang saksi yang dapat dipercaya. Hal ini juga dikenal dengan cacat nasab.

\section{c. Nasab Habaib/Syarifah di Indonesia}

Tak banyak yang tahu darimana asal muasal sebutan Habib. Orang awam hanya paham, Habib identik dengan ustadz keturunan Arab dengan stereotip berjanggut tebal dan bersorban. Publik hanya mengetahui bahwa Habib adalah pendakwah yang harus dihormati.

Jika ditelisik dalam perspektif antropologis, munculnya Habib merupakan fenomena 'penghormatan' terhadap keturunan Nabi Muhammad SAW. Sebutan Habib itu dinisbatkan secara khusus terhadap laki-laki keturunan Nabi Muhammad SAW melalui pernikahan Sayyidah Fatimah az-Zahra ra dengan Sayyidina Ali bin Abi Thalib ra yang berputra Hasan dan Husein serta Zainab.

Istilah Habib umumnya mengacu kepada keturunan Rasulullah SAW yang dari Hadaramaut Yaman. Namun keturunan Nabi Muhammad SAW yang bukan 
dari Hadramaut umunya memakai gelar Sayyid atau Syarif. Bagi para perempuan keturunan Nabi Muhammad SAW, di Indonesia umumnya disebut Syarifah.

Di Indonesia gelar untuk keturunan Rasulullah SAW menjadi bermacammacam. Beberapa diantaranya Yek untuk daerah Jawa, Ayip untuk daerah Palembang dan sekitarnya. Ada pula gelar mereka yang sudah akrab bagi warga Banten dan sekitarnya yakni Tubagus. Gelar Tubagus diberikan bagi keturunan Rasulullah SAW dari fam Azmatkhan. Fam ini diambil dari Sayyid Abdul Malik Sayyid Abdul Malik lahir di kota Qasam, sebuah kota di Hadhramaut, sekitar tahun 574 Hijriah.

Ia juga dikenal dengan gelar "Al-Muhajir Ilallah", karena beliau hijrah dari Hadhramaut ke Gujarat untuk berdakwah sebagaimana kakeknya, Sayyid Ahmad bin Isa, digelari seperti itu karena ia hijrah dari Iraq ke Hadhramaut untuk berda'wah. Menurut Sayyid Salim bin Abdullah Asy-Syathiri Al-Husaini (Ulama' asli Tarim, Hadramaut, Yaman),keluarga Azmatkhan yang merupakan leluhur Walisongo di nusantara adalah dari Qabilah Ba'Alawi atau Alawiyyin asal Hadramaut, Yaman, dari gelombang pertama yang masuk di nusantara dalam rangka penyebaran Islam. Dari trah itulah muncul gelar khusus, yaitu Habib (yang tercinta), Sayid (tuan), Syarif (yang mulia) Tubagus, dan lain sebagainya. Gelar Habib juga berarti panggilan kesayangan dari cucu kepada kakeknya dari golongan keluarga tersebut.

Berdasarkan catatan Rabithah Alawiyah, organisasi yang melakukan pencatatan silsilah para habib, ada sekitar 20 juta orang di seluruh dunia yang menyandang gelar ini. Mereka yang juga disebut alawiyin atau saadah itu terdiri dari 114 marga. Menurut Ar-Rabithah, hanya keturunan laki-laki saja yang berhak menyandang gelar Habib.

Di kalangan Arab-Indonesia, menurut catatan Rabithah Alawiyah, ada sekitar 1,2 juta orang yang 'berhak' menyandang sebutan Habib. Mereka memiliki moyang yang berasal dari Yaman, khususnya Hadramaut. Dari merekalah tersusun silsilah yang menjuntai hingga belasan abad, dari Hadramaut (Yaman) hingga ke Tanah Abang (Jakarta). Yaitu sebuah silsilah keturunan Nabi Muhammad SAW dari garis keturunan Sayyidah Fathimah ra, yang menikah dengan Sayyidina Ali bin Abi Thalib ra. Sebutan yang paling populer untuk 'menghormati' para 
keturunan Nabi Muhammad SAW dari jalur Sayyidah Fathimah ra ini adalah Habib atau Habaib (jamak).

Selain itu, untuk keturunan Rasulullah saw, dengan menarik garis keturunan secara matrilineal (keturunan dari perempuan) di Indonesia dianggap bukan habib meski secara umum masih dinilai sebagai keturunan Rasulullah SAW. Keturunan Rasulullah SAW yang dari jalur Ibu kalau di negara-negara Timur Tengah dan India disebut Mirza.

Para Habib sangat dihormati oleh masyarakat muslim Indonesia, karena dianggap sebagai tali pengetahuan yang murni dari garis keturunan langsung Nabi Muhammad. Penghormatan ini sangat membuat gusar para kelompok anti-sunnah yang mengait-kaitkan hal ini dengan bid'ah. Faktanya, Habaib di Indonesia sangat banyak memberikan pencerahan dan pengetahuan akan agama Islam. Sudah tak terhitung jumlah orang yang akhirnya memeluk agama Islam di tangan para Habib itu.

\section{d. Pandangan Bangsa Arab Terhadap Pentingnya Nasab}

Orang-orang Arab di masa jahiliah dan begitu juga bangsa-bangsa lainnya, banyak yang menisbatkan orang lain dengan nasabnya dengan sesukanya, dengan jalan mengambil anak angkat. Seorang laki-laki boleh memilih anak-anak kecil untuk dijadikan anak, kemudian diproklamirkan. Maka si anak tersebut menjadi satu dengan anak-anaknya sendiri dan satu keluarga, sama-sama senang dan samasama susah dan mempunyai hak yang sama. Mengangkat seorang anak seperti ini sedikitpun tidak dilarang, kendati si anak yang diangkat itu jelas jelas mempunyai ayah dan nasabnya pun sudah dikenal.

Bangsa Arab merupakan bangsa yang sangat memperhatikan dan menjaga nasab dan hubungan kekerabatan, karena mereka tidak lupa nenek moyang mereka. Makanya mereka selalu mengaitkan nama mereka dengan bapak, dan kakek-kakek mereka ke atas. Oleh karena itu dalam nama mereka pasti ada istilah bin atau Ibnu yang artinya anak. Nabi kita Muhammad Saw mengetahui nasabnya sampai beberapa generasi sebelumnya. Nasab beliau adalah Muhammad bin 'Abdullah bin 'Abdul-Muthalib bin Hasyim bin Abdul- Manaf bin Qushay bin Kilab bin Murrah 
bin Ka'ab bin Luay bin Ghalib bin Fihr bin Malik bin Nadhar bin Kinanah bin Khuzaimah bin Mudrikah bin Ilyas bin Mudhar bin Nizar bin Ma'ad bin Adnan. ${ }^{3}$

Bukan hanya Nabi yang seperti itu, hampir seluruh orang-orang Arab mengetahui nasabnya masing-masing sampai beberapa generasi sebelumnya. Hubungan kekeluargaan dan persaudaraan diantara mereka sangat kuat. Allah menjadikan mereka sebagai contoh untuk diteladani. Lalu bagaimana dengan bangsa-bangsa lain dan bangsa kita yang kebanyakan mengetahui hanya sampai kakek dan buyut.

Akibat pengetahuan nasab yang terbatas ini maka efeknya sangat memprihatinkan. Diantaranya tidak mengetahui saudaranya yang jauh, menganggap bahwa dirinya tidak punya saudara, tidak mendapat bantuan dan pertolongan bila dirinya mengalami kesengsaraan, tidak punya tempat untuk mengadu dan meminta pertolongan kecuali orang lain. Akhirnya ujung-ujungnya timbullah kemiskinan, anak gelandangan, dan lain sebagainya. Padahal seandainya mereka mengetahui nasab mereka siapa tahu bahwa direktur perusahaan disamping gubuknya adalah saudaranya dari buyut kakeknya.

Meskipun nasab sangat penting bagi orang Arab, Alquran maupun Hadits Nabi menjelaskan bahwa kemuliaan seorang hamba bukanlah diukur dengan nasabnya, namun dengan ketakwaan dan amal perbuatannya. Hal ini sebagaimana dijelaskan oleh Allah dalam Alquran,

$$
\text { إِنَّ أَكْرَكُمْمْ عِنْدَ اللَّهِ أَتَقَاكْمْ [الحجرات/13] }
$$

Artinya: "Sesungguhnya yang paling mulia diantara kalian di sisi Allah adalah yang paling bertaqwa". (QS. al-Hujarat: 13) ${ }^{4}$

Berkenaan dengan hal tersebut Nabi juga bersabda yang berbunyi,

${ }^{3}$ Sayyid Sabiqt, tt, Fiqh as Sunnah, jilid III, Beirut, Dar as Tsaqafah al Islamiyah, hal 76

${ }^{4}$ Departemen Agama RI, 2010, Al-Qur'an dan Terjemahnya, Bandung : Jabal Raudlotul Jannnah, hal. 416. 


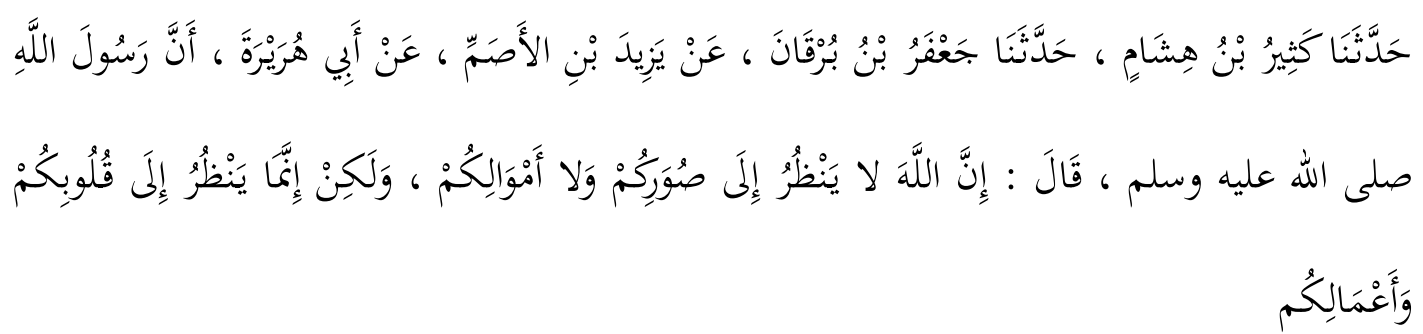

“Ja'far bin Burkon, Katsir bin Hisyam menceritakan kepada kami, diriwayatkan dari Yazid bin al-Ashom, diriwayatkan dari Abi Hurairah bahwa Rasulullah SAW bersabda, "Sesungguhnya Allah tidak memandang bentuk dan harta kalian, akan tetapi hanya saja Allah memandang hati dan amal perbuatan kalian. "5

Dalam Hadits lain Nabi juga bersabda bahwa keselamatan orang Quraisy dan keluarganya adalah ditentukan Allah,

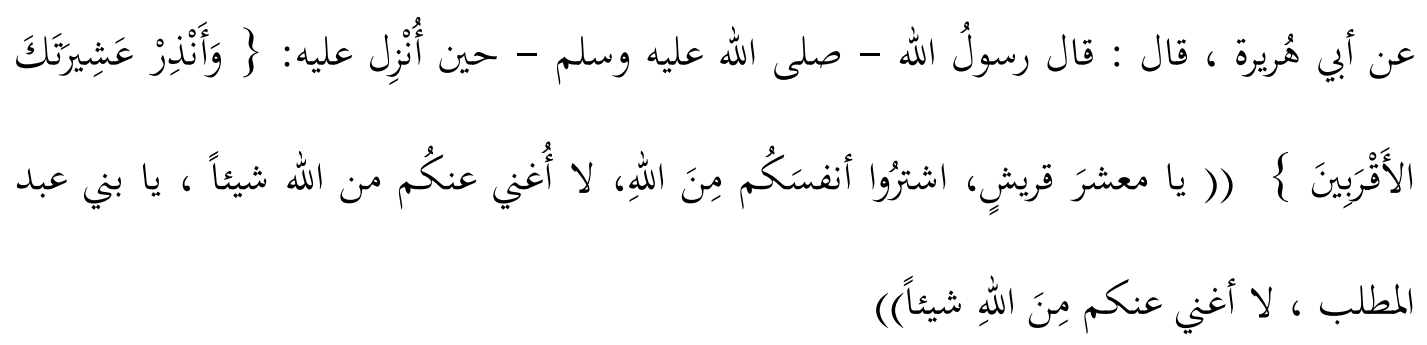

"Diriwayatkan dari Abi Hurairah bahwa Rasulullah SAW ketika dituruni wahyu bersabda, “Wahai kelompok Quraisy, belilah diri kalian dari Allah, aku tidak dapat menjamin kalian sedikitpun dari Allah, wahai Bani Abdul Muthollib, aku tidak dapat menjamin kalian sedikitpun dari Allah. ${ }^{6}$

Adapun yang dimaksud dengan kata-kata "belilah diri kalian dari Allah" adalah selamatkanlah diri kalian dari adzab Allah dengan mengikuti jalan yang telah ditetapkan oleh Allah. Begitulah penjelasan sebagian ulama ketika mensyarahi Hadits di atas. ${ }^{7}$

\section{e. Cara Menentukan Nasab Pada Masa Nabi}

Pada Rasul dan Zaman sahabat untuk menentukan hubungan nasab yakni dengan melihat dari perkawinan yang sah orang tua anak atau orang tersebut. Seorang laki-laki dan perempuan yang menikah dan melahirkan seorang anak,

\footnotetext{
${ }^{5}$ Imam al-Baihaqi, al-Adab Lil Baihaqi, Maktabah Syamilah, Juz 1, Hal. 449

${ }^{6}$ Ibnu Rajab al-Hambali, Jami ul Ulum wal Hikam, Maktabah SYamilah, Juz 24, Hal 29

${ }^{7}$ Imam Syafi'i. (2020). Konsep Kafaah dan Keluarga Sakinah (Studi Analisis Tentang Korelasi Hak Kafa'ah Terhadap Pembentukan Keluarga Sakinah) . Asy-Syariah : Jurnal Hukum Islam , 6 (1),
} 35 . 
maka secara otomatis anak itu dinasabkan kepada kedua orang tuanya dengan catatan tidak ada pengingkaran oleh si suami.

Misalnya Jika seorang istri melahirkan anak yang berkulit hitam padahal kedua suami istri tersebut berkulit putih atau sebaliknya, maka di sini ada dua pendapat. Pertama sang suami boleh tidak mengakui anak tersebut, yaitu karena faktor kemiripan. Kedua suami tidak boleh menolak anak itu, karena mungkin ada kelainan atau penyakit pada anak itu. Dalam masalah ini bisa di bantu oleh seorang $Q a-f a h$, yakni orang yang tahu menetukan nasab berdasarkan kemiripan jasmaniah.

Selain itu juga digunakan sistem al-qiyafa, yakni menurut penglihatan setelah melihat bagian-bagian pada bayi yang baru lahir serta melihat ciri-ciri jasmaniah anak tersebut. Dan salah satu contohnya atau yang saat ini telah diqiyas-kan adalah dalam bentuk sidik jari. Melalui sidik jari tersebut, seseorang ditentukan bahwa inilah sebenarnya hubungannya.

Selain kedua cara di atas, islam juga menggunakan persaksian dan pengakuan (iqrar) untuk menentukan nasab seseorang. Istilhaq/lahiqa atau iqraru bin nasab dipergunakan untuk pengakuan anak atau pengesahan anak, dimana alasan utama dari pengakuan atau pengesahan itu ialah karena ada hubungan darah antara yang mengakui dengan anak yang diakui.

Pengakuan anak/ pengakuan nasab itu ada dua macam[4], yakni pengakuan anak oleh diri sendiri/pengakuan anak langsung), dan pengakuan anak oleh orang lain. Pengakuan anak oleh diri sendiri adalah jika seseorang menyatakan bahwa anak ini adalah anaknya, atau orang itu adalah ayahnya. Menurutnya, pengakuan seperti itu dapat diterima dengan empat syarat:

a) Anak yang diakui tidak diketahui nasabnya. Jika diketahui nasabnya maka pengakuan itu batal, karena tidak diperbolehkan memindahkan nasab seseorang pada nasab orang lain. Dalam Hadits disebutkan:

"Nabi melaknat orang yang bernasab kepada selain ayahnya "

Dalam hal objek pengakuan anak adalah anak dari ibu yang dilian (anak li'an), maka ulama sepakat tidak perlu syarat ini, dan anak lieean tidak boleh diakui sebagai anak kecuali oleh ayah yang meli-an, karena dalam hal ini dia dianggap mencabut pernyataannya yang tidak mengakuinya sebagai anak. 
b) Pengakuan anak tersebut adalah pengakuan yang masuk akal/logis, tidak bertentangan dengan akal sehat, seperti perbedaan umurnya wajar, atau tidak bertentangan dengan pengakuan orang, dan sebagainya.

c) Anak yang diakui menyetujui atau tidak membantah, jika anak yang diakui itu sudah cukup umur untuk membenarkan atau menolak (baligh dan berakal sehat). Demikian pendapat jumhur ulama. Tetapi menurut mazhab Malikiyah, syarat ini tidak diperlukan, karena nasab adalah hak anak kepada ayahnya, karena itu pengakuan anak tidak memerlukan persetujuan anak, sepanjang tidak terbukti pengakuan itu dusta atau tidak benar.

d) Pada anak tersebut belum ada hubungan nasab dengan orang lain. Artinya, jika pengakuan anak itu diajukan oleh seorang isteri atau seorang perempuan beriddah, maka disyaratkan adanya persetujuan dari suaminya tentang pengakuan itu.

Rasulullah sendiri pernah mengangkat seorang anak, yaitu Zaid bin Haritsah sejak zaman jahiliah. Zaid waktu itu seorang anak muda yang ditawan sejak kecil dalam salah satu penyerbuan jahiliah, yang kemudian dibeli oleh Hakim bin Hizam untuk diberikan bibinya yang bernama Khadijah, dan selanjutnya diberikan oleh Khadijah kepada Nabi Muhammad s.a.w. sesudah beliau kawin dengan dia.

Setelah ayah dan pamannya mengetahui tempatnya, kemudian mereka minta kepada Nabi, tetapi oleh Nabi disuruh memilih. Namun Zaid lebih senang memilih Nabi sebagai ayah daripada ayah dan pamannya sendiri. Lantas oleh Nabi dimerdekakan dan diangkatnya sebagai anaknya sendiri dan disaksikan oleh orang banyak. Sejak itu Zaid dikenal dengan nama Zaid bin Muhammad, dan dia termasuk pertama kali bekas hamba yang memeluk Islam.

Islam berpendapat secara positif, bahwa pengangkatan anak adalah suatu pemalsuan terhadap realita, suatu pemalsuan yang menjadikan seseorang terasing dari lingkungan keluarganya. Dia dapat bergaul bebas dengan perempuan keluarga baru itu dengan dalih sebagai mahram padahal hakikatnya mereka itu samasekali orang asing. Isteri dari ayah yang memungut bukan ibunya sendiri, begitu juga anak perempuannya, saudara perempuannya atau bibinya. Dia sendiri sebenarnya orang asing dari semuanya itu. Justru itu Alquran menghapus aturan jahiliah ini dan 
diharamkan untuk selama-lamanya serta dihapusnya seluruh pengaruhpengaruhnya.

Persoalan ini tidak begitu mudah, sebab masalah anak angkat sudah menjadi aturan masyarakat dan berakar dalam kehidupan bangsa Arab. Oleh karena itu dalam kebijaksanaan Allah untuk menghapus dan memusnahkan pengaruhpengaruh perlembagaan ini tidak cukup dengan omongan saja, bahkan dihapusnya dengan omongan dan sekaligus dengan praktik.

Zaid bin Haritsah yang kita kenal sebagai Zaid bin Muhammad, telah dikawinkan dengan Zainab binti Jahsy sepupu Nabi sendiri. Tetapi karena kehidupan mereka berdua selalu goncang dan Zaid sendiri sudah banyak mengadu kepada Nabi tentang keadaan isterinya, sedang Nabi sendiri juga mengetahui keinginan Zaid untuk mencerainya, dan dengan wahyu Allah, Zainab akan dikawin oleh Nabi, tetapi kelemahan manusia tempoh-tempoh sangat mempengaruhi, maka Nabi takut bertemu dengan orang banyak. Oleh karena itu dia katakan kepada Zaid: "Tahanlah isterimu itu dan takutlah kepada Allah!"

Di sinilah ayat Alquran kemudian turun untuk menegur sikap Nabi. Dan seketika itu beliau menyingsingkan lengan bajunya untuk tampil ke tengah-tengah masyarakat, guna menghapus sisa-sisa aturan kuno dan tradisi yang sudah usang yang mengharamkan seseorang mengawini bekas isteri anak angkatnya yang pada hakikatnya dia adalah orang asing itu. Maka berfirmanlah Allah:

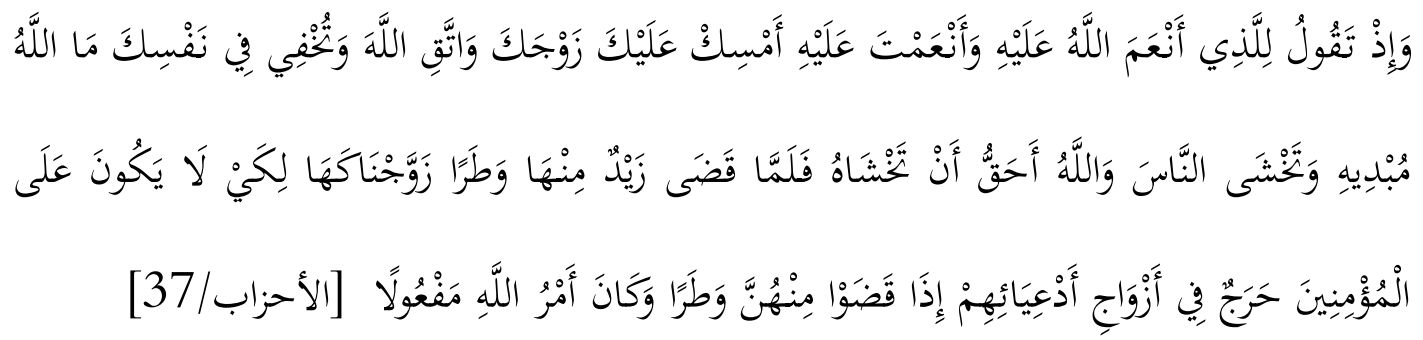

"Dan (ingatlah) ketika engkau berkata kepada orang yang telah diberi nikmat oleh Allah dan engkau juga telah memberi kenikmatan kepadanya (Zaid bin Haritsah): 'tahanlah untukmu isterimu dan takutlah kepada Allah', dan engkau menyembunyikan dalam hatimu apa yang Allah tampakkan, dan engkau takut manusia, padahal Allahlah yang lebih berhak engkau takutinya. Maka tatkala Zaid memutuskan untuk mencerai Zainab, kami (Allah) kawinkan engkau dengan dia, supaya tidak menjadi beban bagi orang-orang mu'min tentang bolehnya 
mengawini bekas isteri anak-anak angkatnya apabila mereka itu telah memutuskan mencerainya, dan keputusan Allah pasti terlaksana." (QS. al-Ahzab: 37$)^{8}$

Begitulah pengangkatan anak yang dihapus oleh Islam; yaitu seorang menisbatkan anak kepada dirinya padahal dia tahu, bahwa dia itu anak orang lain. Anak tersebut dinisbatkan kepada dirinya dan keluarganya, dan baginya berlaku seluruh hukum misalnya: bebas bergaul, menjadi mahram, haram dikawin dan berhak mendapat waris.

\section{f. Cara Menentukan Nasab Pada Masa Modern}

Menentukan nasab pada masa modern seperti sekarang selain dengan melihat anak yang lahir dari perkawinan yang sah juga bisa dilakukan dengan tes DNA (deoxyribo nucleic acid). Tes deoxyrebose nucleic acid (DNA) bukan wacana baru dalam lapangan sains. Tapi bila persoalan itu diusung dalam konteks agamawi, tentu akan menjadi hal yang sangat menarik. Dalam hal ini terdapat perbedaan diantara para ulama, yakni ada yang memperbolehkan dan ada yang tidak memperbolehkan.

Belakangan ini, karena sebab-sebab tertentu, istilah pembuktian anak kandung sering dimuat cetak, dan tak asing lagi di masyarakat, namun sangat sedikit orang mengenal jelas hal ikhwalnya. Pembuktian anak kandung melalui tes DNA adalah berdasarkan teori dan praktek ilmu genetika umat manusia, kecirian mirip di bidang struktur bentuk dan fungsi fisiologi dari generasi filial dan generasi parential, mengadakan analisa terhadap kecirian keturunan, mengadakan pemastian terhadap hubungan kandung yang mencurigakan antara bapak dan anak atau ibu dan anak, dan pada akhirnya mengambil kesimpulan apakah betul atau tidak.

Cara pembuktian anak kandung dari ilmu forensik sebagai berikut, pembuktian melalui tipe darah, perbandingan melalui ciri wajah, pemeriksaan terhadap kurai atau barik-barik kulit, pemeriksaan penyakit keturunan, perbedaan corak, serta membuat inferensi terhadap stadium pembuahan, periode melahirkan dan kemampuan reproduksi.

${ }^{8}$ Departemen Agama RI, 2010, Al-Qur'an dan Terjemahnya, Bandung : Jabal Raudlotul Jannnah, hal. 316 
Tes DNA itu merupakan penemuan pada ilmu kedokteran (Medis) terkini. Sebab pada Rasul dan Zaman sahabat belum dikenal istilah seperti itu. Yang ada pada saat itu adalah sistem al-qiyafa, yakni menurut penglihatan setelah melihat bagian-bagian pada bayi yang baru lahir. Dan salah satu contohnya atau yang saat ini telah di-qiyas-kan adalah dalam bentuk sidik jari. Melalui sidik jari tersebut, seseorang ditentukan bahwa inilah sebenarnya hubungannya.

Dalam tes DNA akurasi tingkat kebenaran sudah mencapai 99,9 persen, dan bisa dijadikan sebagai penetapan bahwa seseorang itu memiliki hubungan dengan yang lain. Oleh karena itu, dalam penetapan masalah DNA tersebut, khususnya masalah ilhaqu al-nasab (hubungan nasab/keturunan), maka berdasarkan hasil tes DNA bisa dijadikan sebagai bagian yang akan mendukung boleh tidaknya seseorang itu diakui sebagai nasab.

Terdapat dua pendapat, yakni dengan hasil tes DNA itu seseorang bisa dinasabkan secara biologis. Artinya yang bersangkutan memiliki hubungan biologis dengan orang tertentu. Tetapi dari segi syar'i, apakah yang bersangkutan tersebut merupakan anaknya atau tidak, hal itu tidak bisa semata-mata berdasarkan hasil tes DNA.

Sebab, dalam menentukan keturunan seseorang itu sah atau tidak, amat terkait dengan proses perkawinan. Seseorang itu diakui dan dianggap sebagai anak yang sah, dan memperoleh hak-haknya dalam waris, apabila ia lahir dari hasil pernikahan yang sah. Nah, karena hasil tes DNA hanya menentukan hubungan keturunan itu secara biologis saja, dan tidak diketahui secara syar'i hubungan tersebut sah atau tidak, maka hal itu tidak bisa serta merta bisa ditentukan sebagai dasar hukum bahwa yang bersangkutan memiliki hubungan yang sah dengan orang lain.

Oleh karenanya, selain melalui tes DNA itu, masih dibutuhkan sekian informasi lainnya untuk menetapkan bahwa yang bersangkutan itu memiliki hubungan dengan orang lain, seperti melalui penyaksian dan lain sebagainya. Sedang tes DNA itu hanya merupakan salah satu bagian saja dari informasi yang banyak tersebut. Jadi hal itu belum bisa diputuskan bahwa yang bersangkutan itu merupakan nasab si A atau si B secara sah (syar'i), sedangkan secara biologis bisa saja hal itu dinasabkan. 
Kesaksian yang didapat berdasarkan syariat yaitu kesaksian dari dua orang laki-laki, beragama islam, sehat rohani, mampu berfikir, dikenal keadilannya. Khusus untuk syarat dua orang saksi yang adil, ia menyaksikan bahwa benar anak itu adalah anak kandung orang tuanya, atau menyaksikan bahwa anak itu adalah hasil dari perkawinan yang sah, atau menyaksikan bahwa anak itu sudah dikenal dan tidak diragukan lagi oleh masyarakat bahwa ia adalah anak kandung orang tuanya. Di samping itu kesaksian dapat juga melalui ketetapan atau keputusan dalam majelis hukum yang menyatakan bahwa anak tersebut benar anak kandung dari orang tuanya.

Tes DNA itu hanya merupakan salah satu alat untuk bisa mengetahui bahwa yang bersangkuta itu memiliki hubungan atau tidak memiliki hubungan dengan yang lain (menafikan). Jadi bukan untuk menentukan bahwa dia memiliki hubungan dengan yang lain atau menisbatkan.

Dalam salah satu hadis disebutkan bahwa al-waladu li al-firasy, artinya anak keturunan itu, harus berdasarkan hubungan suami isteri yang sah. Jadi tes DNA hanya untuk lebih menguatkan (qorinah) saja. Dan dalil ini sudah sangat tegas menjelaskan masalah tersebut.

Sedangkan dari segi kajian usul fikihnya, hal itu dikhawatirkan akan menimbulkan kerancuan dalam masalah nasab. Sebagaimana salah satu kaidah usul fikih yang menyatakan, dar' ul-mafasid muqaddamun 'ala jalbi al-mashalih, menolak sesuatu yang akan menimbulkan kerusakan harus lebih didahulukan daripada menarik sedikit kemashlahatan. Jadi karena dianggap akan mengaburkan permasalahan nasab, maka tes DNA boleh dilakukan sebagai qorinah atau menguatkan masalah tersebut, tetapi tetap tidak bisa dijadikan sebagai nasab syar'i. Karena selain masih banyak informasi lain yang harus dibutuhkan untuk menetapkan masalah ini, juga harus dibuktikan dengan nasab syar'i, yakni melalui pernikahan yang sah.

Jadi pada intinya ulama yang tidak setuju berpendapat pada zaman nabi memang belum ada teknologi DNA. Penentuan nasab dalam hukum Islam hanya bersumber dari pernikahan yang sah, persaksian, dan pengakuan. Menurut ulama yang menolak menjadikan hasil uji DNA sebagai sumber baru penentuan nasab seseorang, berdasar pada dalil ini. 
Sedangkan yang setuju dengan tes DNA sebagai salah satu cara menentukan nasab berkata bahwa pada zaman nabi, ada hadis yang menyatakan soal qo'if, yaitu orang yang bisa memprediksi secara akurat bahwa seseorang masih punya nasab dengan orang lain hanya berdasarkan bekas tapak kaki mereka. Dalil tentang qo'if ini yang kemudian dijadikan rujukan kiai-kiai yang menerima tes DNA sebagai sumber baru.

\section{g. Urgensi Nasab dalam Islam}

Bicara tentang hak anak dalam Islam, pertama sekali secara umum dibicarakan dalam apa yang disebut sebagai dharuriyatu khamsin (hak asasi dalam Islam). Hak itu adalah lima hal yang perlu dipelihara sebagai hak setiap orang: 1 . Pemeliharaan atas hak beragama (hifdzud dien); 2. Pemeliharaan atas Jiwa (hifdzun nafs). 3. Pemeliharaan atas Akal (hifdzul aql); 4. Pemeliharaan atas Harta (hifdzul mal); 5. pemeliharaan atas keturunan/nasab (hifdzun nasl) dan Kehormatan (hifdzul 'ird).

Jika merinci hak-hak anak yang diperolehnya dari orangtua atau otoritas lainyang menggantikan orangtua, maka kita akan dapati bahwa hak-hak tersebut merupakan penjabaran dari Dharuriyatu Khamsin tadi. Misalnya hak anak untuk mendapatkan nama dan keturunan nasab maka itu ada dalam pemeliharaan atas nasab dan kehormatan, hak untuk mendapatkan pendidikan yang layak, dapat dimasukkan ke dalam pemeliharaan atas agama (mendapatkan pendidikan akhlaqul karimah) dan pemeliharaan atas akal, dan seterusnya. Sebagaimana kita ketahui, kehormatan seseorang seringkali dikaitkan dengan keturunan siapakah dia. Dan jika seorang anak dikenal sebagai anak tak berbapak, maka hampir pasti ia akan mengalami masalah besar dalam pertumbuhan kepribadiannya kelak karena ketidak jelasan status keturunan. ${ }^{9}$

Demi menjaga hal tersebut, Islam melarang seseorang menghapus nasab/nama keturunan dari ayah kandungnya. Selain masalah psikologis dan perkembangan kepribadian anak, masalah nasab atau keturunan juga berkaitan dengan muharramat yaitu aturan tentang wanita-wanita yang haram dinikahi (dianggap incest/menikah seketurunan).

9 Ahmad Muzakki, \& Himami Hafshawati. (2021). Kedudukan dan Standarisasi Kafaah dalam Pernikahan Perspektif Ulama Madzhab Empat. Asy-Syari'ah : Jurnal Hukum Islam, 7(1), 34. 
Dalam tata hukum Islam (Fiqih), masalah ikatan darah atau keluarga menjadi masalah yang mempunyai dampak luas, karena dari tes itulah bisa diketahui nasab (keturunan keluarga atau silsilah). Silsilah tidak hanya berdampak pada masalah generatif semata, namun juga berdampak pada masalah hukum dan sosial.

Peringatan keras bagi orang-orang yang dengan sengaja menyembunyikan siapa ayahnya dan mengetahui nasabnya, namun dia sengaja menyembunyikannya atau mengingkarinya, dikarenakan perbuatan tersebut (menyembunyikan nasab) bisa mengakibatkan pencampuran mahram, terputusnya hak waris, memutuskan hubungan kekerabatan dan lain-lainnya.

Di dalam hukum Islam, nasab mempunyai peran yang sangat penting. Dengan jelasnya status nasab seseorang, hukum-hukum yang berkait dengan hal ini juga akan jelas. Semisal tentang perkawinan. Dengan kepastian bahwa seorang laki-laki mempunyai ikatan darah dan masih menjadi muhrim seorang perempuan, haram hukumnya bagi kedua orang ini untuk melakukan perkawinan.

Atau untuk menentukan apakah seseorang itu berhak mendapat warisan dari orang yang telah meninggal. Kepastian nasab mempunyai peran yang sangat vital, sebab dalam hukum Islam waris sudah diatur dengan tegas. Namun, mobilitas yang tinggi dari masyarakat, bisa membuat dua orang bersaudara yang masih muhrim tidak saling kenal. Bisa karena jarak yang memisahkan atau karena alasan lain sehingga mereka memang tidak saling kenal.

Sedangkan diantara kegunaan mempelajari ilmu nasab adalah : Pertama, mengetahui nasab nabi Muhammad saw yang merupakan suatu keharusan untuk sahnya iman. Ibnu Hazm berkata : diantara tujuan mempelajari ilmu nasab agar seseorang mengetahui bahwasanya nabi Muhammad saw diutus oleh Allah swt kepada jin dan manusia dengan agama yang benar, Dia Muhammad bin Abdullah al-Hasyimi al-Quraisy lahir di Makkah dan hijrah ke Madinah. Siapa yang mempunyai keraguan apakah Muhammad saw itu dari suku Quraisy, Yamani, Tamimi atau Ajami, maka ia kafir yang tidak mengenal ajaran agamanya.

Kedua, sesungguhnya pemimpin itu berasal dari suku Quraisy. Berkata Ibnu Hazm : Dan tujuan mempelajari ilmu nasab adalah untuk Smengetahui bahwa 
seseorang yang akan menjadi pemimpin harus anak cucu Fihr bin Malik bin Nadhir bin Kinanah.

Ketiga, untuk saling mengenal di antara manusia, hingga kepada keluarga yang bukan satu keturunan dengannya. Hal ini penting untuk menentukan masalah hukum waris, wali pernikahan, kafaah suami terhadap istri dalam pernikahan dan masalah wakaf. ${ }^{10}$

Dari Abu Dzar al-Ghifari, Rasulullah saw bersabda :

'Tidaklah seorang yang mengaku bernasab kepada lelaki yang bukan ayahnya, sedangkan ia mengetahuinya maka ia adalah seorang kafir. Dan siapa yang mengaku bernasab kepada suatu kaum yang bukan kaumnya, maka bersiaplah untuk mengambil tempat duduknya di neraka'.

Dari sisi ini tampak jelas sekali bukti betapa pentingnya untuk mengenal atau mengetahui nasab seseorang itu, sehingga berusaha untuk mempelajari masalah yang berkenaan dengan nasab tersebut wajib hukumnya, minimal fardlu kifayah. Dan yang perlu diingat bahwa untuk menjaga kemurnian nasab tidak ada cara lain selain melalui perkawinan yang sah.

Meskipun nasab sangat penting bagi orang Arab, Alquran maupun Hadits Nabi menjelaskan bahwa kemuliaan seorang hamba bukanlah diukur dengan nasabnya, namun dengan ketakwaan dan amal perbuatannya. Hal ini sebagaimana dijelaskan oleh Allah dalam Alquran,

$$
\text { إِنَّ أَكْرَكُمْمْ عِنْدَ اللَّهِ أَتَقَاكْمْ [الحجرات/13] }
$$

Artinya: "Sesungguhnya yang paling mulia diantara kalian di sisi Allah adalah yang paling bertaqwa”. (QS. al-Hujarat: 13) ${ }^{11}$

Berkenaan dengan hal tersebut Nabi juga bersabda yang berbunyi,

${ }^{10}$ Wahbah Zuhaily, 1989, Al Fiqhu al Islami wa Adillatuh, Beirut, Darul Fikr, jilid VII, cet. III.

${ }^{11}$ Departemen Agama RI, 2010, Al-Qur'an dan Terjemahnya, Bandung : Jabal Raudlotul Jannnah, hal. 416 


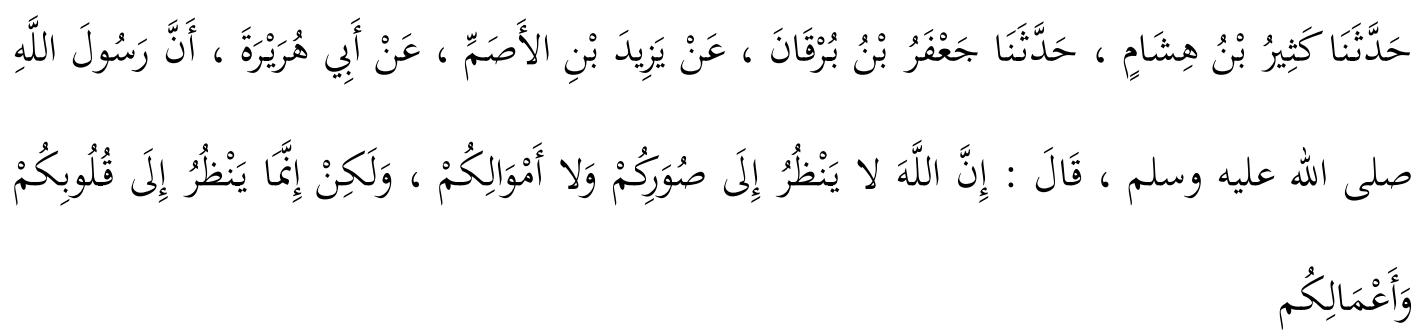

“Ja'far bin Burkon, Katsir bin Hisyam menceritakan kepada kami, diriwayatkan dari Yazid bin al-Ashom, diriwayatkan dari Abi Hurairah bahwa Rasulullah SAW bersabda, "Sesungguhnya Allah tidak memandang bentuk dan harta kalian, akan tetapi hanya saja Allah memandang hati dan amal perbuatan kalian. "12

Dalam Hadits lain Nabi juga bersabda bahwa keselamatan orang Quraisy dan keluarganya adalah ditentukan Allah,

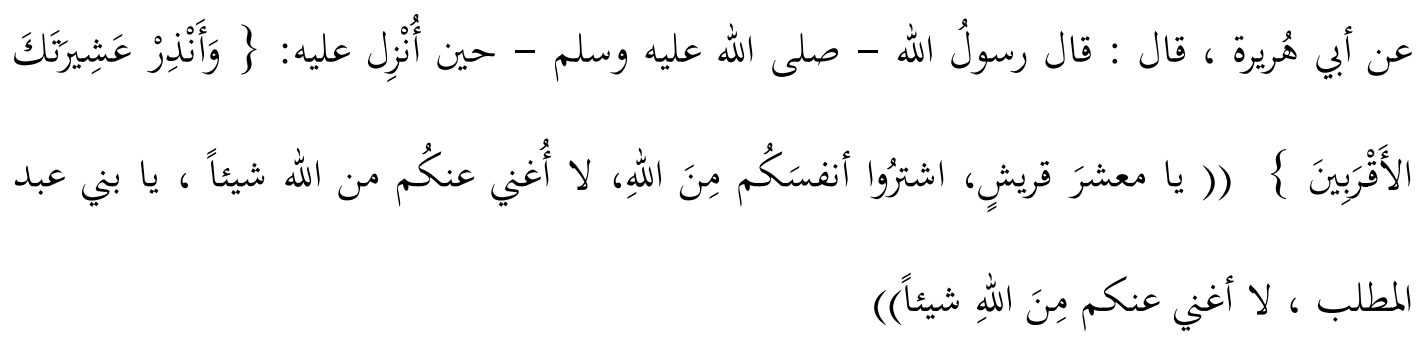

"Diriwayatkan dari Abi Hurairah bahwa Rasulullah SAW ketika dituruni wahyu

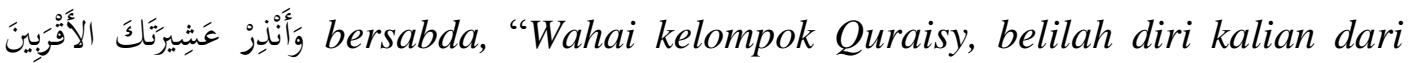
Allah, aku tidak dapat menjamin kalian sedikitpun dari Allah, wahai Bani Abdul Muthollib, aku tidak dapat menjamin kalian sedikitpun dari Allah. ${ }^{13}$

Adapun yang dimaksud dengan kata-kata "belilah diri kalian dari Allah" adalah selamatkanlah diri kalian dari adzab Allah dengan mengikuti jalan yang telah ditetapkan oleh Allah. Begitulah penjelasan sebagian ulama ketika mensyarahi Hadits di atas.

\footnotetext{
${ }^{12}$ Imam al-Baihaqi, al-Adab Lil Baihaqi, Maktabah Syamilah, Juz 1, Hal. 449

${ }^{13}$ Ibnu Rajab al-Hambali, Jami`ul Ulum wal Hikam, Maktabah SYamilah, Juz 24, Hal 29
} 


\section{KESIMPULAN}

Nasab adalah pertalian kekeluargaan berdasarkan hubungan darah melalui akad perkawinan yang sah. Nasab adalah hubungan antara orang yang satu dengan orang tua atau leluhurnya ke atas. Disyariatkannya pernikahan adalah untuk menentukan keturunan menurut Islam agar anak yang lahir dengan jalan pernikahan yang sah memiliki status yang jelas. Artinya anak itu sah mempunyai bapak dan mempunyai ibu. Bangsa Arab merupakan bangsa yang sangat memperhatikan dan menjaga nasab dan hubungan kekerabatan, karena mereka tidak lupa nenek moyang mereka. Makanya mereka selalu mengaitkan nama mereka dengan bapak, dan kakek-kakek mereka ke atas. Sedangkan dalam hukum Islam, nasab mempunyai peran yang sangat penting. Dengan jelasnya status nasab seseorang, hukum-hukum yang berkait dengan hal ini juga akan jelas. Semisal tentang perkawinan. Dengan kepastian bahwa seorang lakilaki mempunyai ikatan darah dan masih menjadi muhrim seorang perempuan, haram hukumnya bagi kedua orang ini untuk melakukan perkawinan. 


\section{DAFTAR PUSTAKA}

Ahmad Muzakki, \& Himami Hafshawati. (2021). Kedudukan dan Standarisasi Kafaah dalam Pernikahan Perspektif Ulama Madzhab Empat. Asy-Syari'ah : Jurnal Hukum Islam, 7(1).

Anshariy, Abu Yahya Zakariya al-. Asna al-Mathalib fi syarh Raudlat al-Thalib. Berut: Dar al-Fikr, tt.

Baidlawiy, Muh. Syairaziy al-. Anwar at-Tanzil wa Asrar at-Ta'wil Beirut: Dar Ihya' atTurats al-Arabiy, 1998.

Bujairimiy, Sulaiman ibn Muhammad ibn Umar al-. Hasyiyah al-Bujairimiy 'ala Syarh alManhaj. Mesir: Mushthafa al-Babiy al-Halabiy, 1950.

Bukhari, Moh. ibn Ismail al-. Al-Jami' al-Musnad as-Shahih. Damaskus: Dar Thuq anNajah, 1997.

Damisyqiy, Musthafa al-Midaniy ad-. At-Tadzhib fi Adillat Matn al-Ghayah wa at-Taqrib juz-I. Beirut: Dar Ibn Katsir, 1989.

Dawud, Sulaiman ibn Asy'as Abu. Sunan Abi Daud. Beirut: al-Maktabah al-'Ashriyah, tt.

Departemen Agama RI, 2010, Al-Qur'an dan Terjemahnya, Bandung : Jabal Raudlotul Jannnah.

Dimyathiy, Abu Bakar Usman ibn Muhammad Syatha al-. I'anat al-Thalibin 'ala Hall Alfadh Fath al-Mu'in. Beirut: Dar al-Fikr, 1997.

Hadlramiy, Said ibn Saad ibn Nabhan al-. 'Iddat al-Faridl fi 'Ilmal-Fara'idl. Jatirogo: Kampoeng Kyai, 2014.

Ibnu Rajab al-Hambali, Jami`ul Ulum wal Hikam, Maktabah Syamilah.

Imam al-Baihaqi, al-Adab Lil Baihaqi, Maktabah Syamilah, Juz 1.

Imam Syafi'i. (2020). Konsep Kafaah dan Keluarga Sakinah (Studi Analisis Tentang Korelasi Hak Kafa'ah Terhadap Pembentukan Keluarga Sakinah) . Asy-Syariah : Jurnal Hukum Islam , 6 (1).

Sayyid Sabiqt, tt, Fiqh as Sunnah, jilid III, Beirut, Dar as Tsaqafah al Islamiyah.

Wahbah Zuhaily, 1989, Al Fiqhu al Islami wa Adillatuh, Beirut, Darul Fikr.

Yusuf al-Qadhawi, 2006, Halal dan Haram dalam Islam, Jakarta: Rabbani Press. 